\title{
Water quality management through community engagement in Costa Rica
}

\author{
Thomas Shahady ${ }^{1}$ (D) $\cdot$ Helen Boniface ${ }^{1}$
}

Published online: 13 July 2018

(C) The Author(s) 2018

\begin{abstract}
Concerns about stream water quality are increasing in Latin America. Poor sanitation infrastructure coupled with a high demand from agricultural development, recreational use, drinking, and sanitation creates a strong need to balance water quality and quantity to meet these demands. Wastewater from various levels of development combined with changes in climate and rainfall patterns has created unique watershed management challenges. Ecologically, tropical river watersheds with their unique hydrology (wet and dry seasons), steep slopes, characteristically long shape, and rapidly changing life zones present management challenges. Sociologically, weak overall protective legislation, streambed manipulation, withdrawals, minimal wastewater treatment, and beliefs water is abundant have produced a lax attitude for protection. To assess these concerns, we studied three river watersheds within a biological corridor along a northern Pacific slope in Costa Rica. We characterized baseline river water quality and then paired biological and chemical parameters to develop an index of water quality. Results suggest agricultural inputs and withdrawal, greywater urban inputs, community water use, and natural features of the watershed including climate concerns must be managed together to improve water quality and provide adequate water resources. Community involvement, along with a water quality index useable by the general public, was a key to the overall success of the project.
\end{abstract}

Keywords Water quality $\cdot$ Tropical rivers $\cdot$ Biomonitoring $\cdot$ Citizen science $\cdot$ Costa Rica

\section{Introduction}

Water quality is one of the most pressing and import issues facing Latin America and the world (Hidalgo León et al. 2015). Developmental pressures, agricultural development, pollutant runoff, inadequate sanitation, and legislation contribute to a pattern of decline. Additional stressors such as seasonable patterns in precipitation, challenging terrain, lack of adequate water quality monitoring, and ineffective water resource management plague efforts to reverse this decline in the tropics (Bower 2014). Further compounding these problems, multiple studies suggest climate change will impact biodiversity, environmental services, agricultural activities, and many other aspects important to water resources (Trenberth et al. 2003; Karmalkar et al. 2008; Bradley and Diaz 2010; Karmalkar et al. 2011).

Thomas Shahady

Shahady@lynchburg.edu

Helen Boniface

Boniface_h@lynchburg.edu

1 Lynchburg College, Lynchburg, VA, USA
Solutions remain elusive. Governmental accountability, corruption, lack of community engagement, and poor management hinder efforts toward effective water and watershed planning (Montgomery and Elimelech 2007). Central American governments remain highly centralized inhibiting local decision making important to key environmental issues (Andersson and Gibson 2006). Often, information is scarce, needed environmental testing complex, and involvement minimal. An effective and useable water monitoring methodology readily available for community use would be a positive step toward community engagement and effective water resource management.

Communities would use such gained information to generate government funding and create partnerships (DelgadoSerrano et al. 2017). Additional benefits include increased scientific literacy, heightened issue awareness, time, and monetary savings. Where monitoring programs enjoy success, legislation is strengthened and water resource management effective (Conrad and Hilchey 2011). Community science often paves the way for acceptance of technologies, future projects, and programs to protect water quality. Before elaborating on the specific analyses undertaken, we introduce the topic of water quality in the tropics, water protection legislation in 
Costa Rica specifically, and water quality monitoring to orient the reader to topic and challenges faced.

\section{Tropical rivers and water quality}

Costa Rica, similar to other Central American countries, contains an abundant supply of water annually; however, precipitation is disproportionately spread between wet and dry seasons. And within seasonal patterns, the climate is changing (Waylen et al. 1996; Amador et al. 2006). More intensive but less annual precipitation (5-10\%) and reduced amounts of surface water runoff (10-30\%) are predicted (Hidalgo et al. 2013). River and groundwater dynamics are changing as well (Hamilton 2010). Because precipitation drives river systems (Plink-Björklund 2015), our current understanding of river water quality and quantity may be challenged.

Tropical rivers, surrounding floodplains, and groundwater are interconnected as a system. The river portion of these systems are flashy, exhibiting low flow during the dry season and flood pulses during heavy rains (Wantzen et al. 2008). Dry season river flow is fed by groundwater while rainy season precipitation floods pulse through river channels, wetlands, floodplains and into adjacent groundwater (Zurbrügg et al. 2012). Conceptually, precipitation connects these surface water resources to groundwater, creating an impact on water quality largely determined by the strength of that connection (Banks et al. 2011). Contamination travels between aquifers and rivers driven by unique connections in any particular watershed. Water resource management must consider both surface and groundwater dynamics as a collective unit.

Direct use of rivers as a drinking water source in Costa Rica is minimal (less than $25 \%$ of country) (Macías et al. 2017). Domestic wastewater discharges are minimal to rivers as well instead directly discharging into groundwater through septic systems (76\% of country according to Macías et al. 2017). Greywater (kitchen, bath, and laundry water separated from sewage) flows directly into local streets and streams untreated (Hidalgo León et al. 2015; Dallas et al. 2004). Even with a dependence on groundwater to provide septic tank effluent sanitation, the availability of potable water in Costa Rica is generally good and serves upward of $99 \%$ of the population (Arias 2010).

Collective wastewater treatment (independent of septic systems) is highly lacking in Costa Rica. While collection in urban areas may be high (up to $96 \%$ ), only $3-4 \%$ is treated before release into surface waters (Arias 2010; Bower 2014). The hotel and tourism industry is not much better with only $20 \%$ of wastewater treated from hotels (Mejia 2014) while roughly $70 \%$ is discharged without treatment directly into streams (FAO 2012). In all communities, septic tanks are the primary means of sewage treatment, although in urban areas, larger treatment plants are under construction. Soils in Costa Rica do not provide good percolation rates for septic tank drain fields with estimates of $150 \mathrm{mg} / \mathrm{L}$ of BOD, pathogens, and odor discharged from typical septic effluents (Arias 2010). This is a continual cause of concern.

Agricultural waste is another source of water contamination. Crops and livestock are irrigated often through direct diversion of streams (Mekonnen et al. 2015). With the passing of the Central America Free Trade Agreement (CAFTA), foreign investment flow into Costa Rica increased dramatically (Miller et al. 2010). This moved food production toward multinational conglomerates developing concentrated animal feeding operations (CAFOs) or industrialized monocultures replacing once smaller farming operations. CAFOs are highly polluting to streams and degrade water quality (Burkholder et al. 2007). Pesticide and nutrient runoff are known to have negative impacts on human and environmental health (de la Cruz et al. 2014; Kumar et al. 2013; Echeverría Sáenz et al. 2012). Wastewater flowing from concentrated lagoons or agricultural runoff impacts streams for long distances into communities.

\section{Legislation of water protection in Costa Rica}

Water quality is managed by the central government in San Jose (the capital) and through a variety of five government agencies and two laws. Unlike strict biodiversity and forest protection legislation, water resource protection is disparate by comparison. The first applicable law is the 1942 Water Law (Ley de Aguas). This law is quite outdated for contemporary use and haw withstood any appreciable revision due to corporate and other interests. This law describes the structure of water rights and charges the first of five government agencies: the Ministry of Environment, and Energy and Telecommunications (MINAET) with ultimate responsibility to manage water resources. The second applicable law concerning water protection is the 1973 General Law of Health (Ley General de Salud). This law charges the second of five government agencies: the Ministry of Health (MOH) with extensive responsibilities related to water quality and disease. The $\mathrm{MOH}$ is directly responsible for health concerns through multiple sectors of society (commercial, domestic, governmental) with greater executive power and resources than MINAET at the local level. A third government agency, the National Groundwater, Irrigation and Drainage Service (SENARA), permits the operation of irrigation and stormwater systems. This agency, although not directly managing water quality, is very important because they oversee, advise, design, and grant permits for all drainage and irrigation projects. Their oversight and permit authority directly impacts water quality based upon land disturbance and construction projects.

The fourth of five government agencies regulating water quality, the Water and Sanitation Service (Aqueductos y Alcantarillados or AyA), is the regulatory authority for 
drinking water and sewage treatment. AyA regulates drinking water by constructing, planning, operating, designing, and financing water supply and sewage systems. They additionally delegate responsibility and provide technical assistance to the fifth and final agency: the Local Water Boards (Administrative Associations of Rural Water and Sanitation Systems or ASADAS) in rural areas. ASADAS are community-based organizations elected locally to provide and protect local water resources. These elected officials provide systems for potable drinking water but do not offer treatment of wastewater or greywater (Hidalgo León et al. 2015). One of their most important considerations is bacterial drinking water contamination. To be potable and drinkable, a $100 \mathrm{ml}$ sample shall not contain any coliform or Escherichia coli bacteria (Arias 2010).

Development is leading to over-exploitation of water resources particularly during the dry season in Costa Rica (Kuzdaz and Wiek 2014). Unclear governmental responsibility and regulation does not effectively manage these concerns. All water usage is regulated through the 1942 Water Law and MINAET, but water diversion and land disturbance is specific to SENARA. These agencies operate and provide permits on a national level. Locally, AyA through the ASADAS and $\mathrm{MOH}$ under the General Law of Health specifically manages water locally (de Albuquerque 2009; Bower 2014). Local and national overlap of authority and ambiguities in Ley de Agua does not create a system of comprehensive water management. On a national level, SENARA directly overlaps with MINAET concerning well drilling and surface water control (Bower 2014). ASADAS and MOH coordinate local water concerns, but MINAET and AyA maintain broad authority. These disparities in clear regulatory authority leave wastewater and greywater generally unregulated (Bower 2014).

Separate from water and health law, Costa Rica has developed a national Payments for Ecological Services (PSA) program. This law grants governmental authority to pay landowners for certain ecological services. The services include biodiversity preservation and hydrological services including water purification, carbon fixation, and scenic beauty. Funding for the PSA occurs from a tax on fossil fuels $(3.5 \%)$, generating payments and management of this program (Pagiola 2008). Further, the National Biological Corridor Program (NBCP) created through the MINAET executive order expands PSA protection by connecting forest parcels. But unlike the PSA program, corridor participants do not receive compensation. These corridors do, however, connect resources along vital stream riparian corridors enhancing the envisioned protections of the PSA program. Results are promising. Sekercioglu (2009) found riparian stream corridors that provide an $80 \%$ return rate of bird species opposed to a
$40 \%$ rate in similar pastureland. Corridors empower stakeholders toward sustainability and create structure for conservation programs.

\section{Challenges of effective water quality management}

While agricultural, governmental, and legal issues challenge effective management, the physical terrain may present the greatest challenge to overcome. Steep and rugged slopes often limit adequate access points to monitor streams. Heavy rains washout existing roads and prevent access without experienced knowledge of local infrastructure. The availability of equipment, adequate laboratory space, and analytical knowledge are limited. Considerable time, maintenance of trucks, water quality expertise, and local knowledge are needed to monitor water quality. Greater technical and financial resources must be applied to this problem to find effective solutions (de Albuquerque 2009).

Additionally, good assessment of water quality demands an understanding of the natural variation present in tropical systems (Jacobsen et al. 2008). The most effective monitoring parameters (chemical, physical, or biological) remain unclear (Shahady and Boniface, in prep). North-temperate countries, faced with a similar situation many decades ago, assessed all parameters, finding aquatic insects were most useful (Jacobsen et al. 2008). Yet, an effective macroinvertebrate index useable in the tropics has proven difficult to create (Kohlmann et al. 2015). Without good data or water quality indices, local communities use anecdotal assumptions as a basis for decision making. A clear and useable methodology is needed for water quality prediction that takes advantage of local community concerns and is easily measured.

Monitoring aquatic insect communities remains a possible solution. Aquatic insect indices quickly and effectively monitor water quality at a fraction of the cost of alternative monitoring approaches (Resh 1995). Aquatic biomonitoring is a well-established technique for assessing water quality of streams (Cairns and Pratt 1993; Karr and Chu 1999). This technique, developed throughout North America and Europe, uses the presence and absence of aquatic insects through standardized indices to predict water quality (Sedeno-Diaz et al. 2012; Zamora-Munoz et al. 1995). This assumption relies upon a rich and identified biodiversity of insects under pristine river conditions and loss of these insects as stream water quality degrades.

The Costa Rican government implemented the use of the biological monitoring working party (BMWP-CR) index in 2007 as a biomonitoring index for stream water quality (MINAE 2007). This index standardizes the use of aquatic insects for water quality detection. The index requires certain collection methodologies to obtain adequate numbers of insects for proper use. Additionally, identification of the insects to the family level requires expertise in aquatic entomology 
and adequate reference material. Some identifications may involve extensive research as some species have yet to be identified (Meyer Guevara Mora, personal communication, May 2016).

The use of a more general index seems appropriate for community engagement if water resource management can be achieved. Using an index based upon more general and easily identified taxonomy solves complexity problems and accessibility for communities. Novak and Bode (1992) developed the percent model affinity (PMA) using a simplified taxonomy. The index uses the percentage of insect orders (this is a simpler classification than insect family used by the BMWP index), comparing undisturbed sections of a stream to impaired sections determining water quality by comparison.

The field of citizen science shows a promise in making the connection between needed water monitoring and confusing water regulation. Dickinson et al. (2010) demonstrate a connection between ecological research and problem solving using this approach. Aquatic insect collection and identification taught to local communities will, at a minimum, engage communities and possibly create an effective water monitoring program. By teaching communities how to monitor these insect assemblages and developing an easily useable index, a connection develops between the community and water quality. This connection potentially bridges the gap between legislation and water quality solutions needed in Costa Rica and Latin America.

\section{Study goals and objectives}

The goals of this research were first to quantify river water quality from cloud forest headwater streams flowing through differing land use in a defined biological corridor along the northern Pacific slope of Costa Rica. To achieve this quantification, each study site was selected to represent a particular land use, such that observed water quality could be associated with this land use. Secondly, each study site represented a specific legislative control objective such as protected forest, agriculture, or neighborhood to represent the efficiency in management of various regulatory agencies. As a third goal, each site represents a differing position in elevation on the slope aligning with the land use and regulatory authority in management.

Thus, this study represents, though each site, PSA management in the headwater regions and other government regulatory authorities throughout the remainder of the biological corridor. In the concentrated neighborhood study sites, ASADAS and AyA are important regulatory agencies. In the mid and lower slope study sites, SENARA permits for land disturbance and agriculture land use that are important water quality drivers. MINAET and MOH work throughout the corridor but concentrate their effort in upper sites as ecotourism is very important in this region. The lower study sites in this corridor are generally unregulated. It was our desire in this study to document and contrast the protected and heavily regulated upper river sites with degrading conditions flowing down the slope and corridor.

The specific objectives of this research were as follows:

- To quantify river bacteriological and nutrient water quality in a biological corridor originating in PSA tropical montane cloud forest

- To compare a taxonomically complex water quality index (BMWP-CR) to a taxonomically simple index (PMA) in these rivers

- To suggest efficacy of the PMA index for water quality testing for communities in Costa Rica

- To analyze these findings in the current legislative environment

\section{Methodology}

\section{Study sites}

This study is part of a larger water quality-monitoring project established in the Bellbird Biological Corridor (Corredor Biológico Pájaro Campana). There are 16 sampling sites throughout the study area spanning a diversity in elevation from near sea level close to the Gulf of Nicoya, up through the town of Monteverde at $1555 \mathrm{~m}$ (Fig. 1). Sites represent a variety of 11 life zones that are included within the corridor covering three watersheds: Aranjuez, Guacimal, and Lagartos.

For this analysis, sampling sites are divided into groups representing upper, middle, and lower portions of the corridor. The upper sites include two areas in the Monteverde Cloud Forest Reserve (RMV and BS) within the headwaters of the Guacimal River. The Monteverde Reserve is an area of biological conservation containing primary and secondary cloud forests originally established by Quakers that founded the area. The headwaters of the Lagartos River are located in the town of Santa Elena. This is a small town with 6500 residents with developed roads, neighborhoods, and businesses. A site inside the neighborhood of Las Llanos (LL) represents the headwaters of the Lagartos River. This area contains urban dense land use for Costa Rica with abundant greywater and overland stormwater flow. The other headwater stations located on the Aranjuez River (BC) is just below another reservethe Children's Eternal Rainforest (Bosque Eterno de los Niños). While the location is much lower in elevation, the characteristics are similar to headwaters of the Guacimal River.

The mid elevation sites are all located within pasture and farming communities. Two sites are located along the 


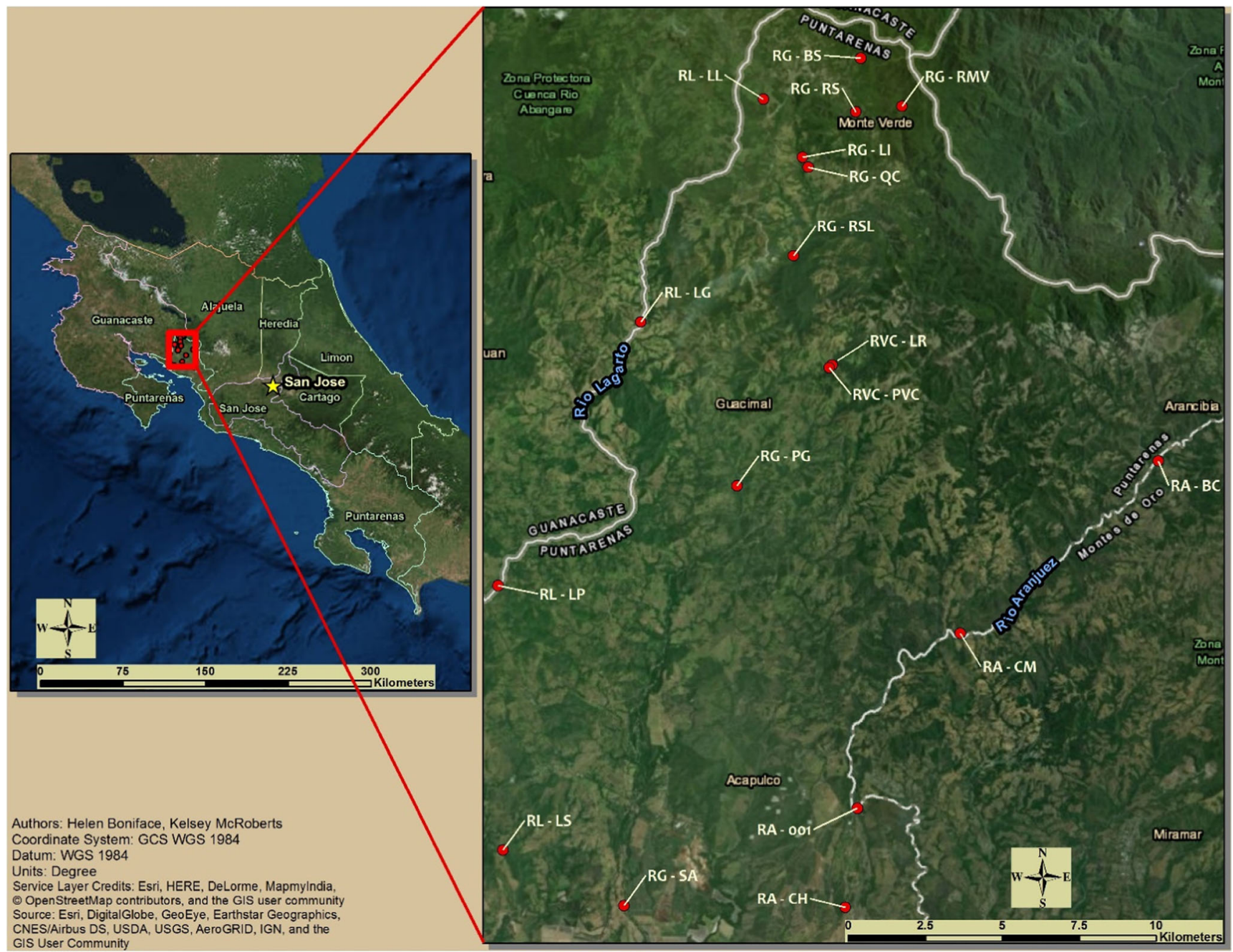

Fig. 1 Map of the study area located along the Pacific slope in Guanacaste Province. The sample sites (indicated by red dots) align along three major river systems (from left to right: Lagartos, Guacimal, and Aranjuez)

Guacimal River. One site in the town of Guacimal (PG) includes pastures and farming. The other sites originate in the biological preserve of the Children's Eternal Rainforest (LR). Sites on the Lagartos River are located directly in a pasture (LG) while areas sampled on the Aranjuez River flow from a hydroelectric plant (CM). The lower elevation sites are all located in disturbed areas. The Lagartos location flows through a developed neighborhood (LP) and then into agricultural (sugar cane) sites (LS). Along the Guacimal River, the sample site is a part of a channelization project diverted for irrigating crops $(\mathrm{CH})$. The site in the Aranjuez River (SA) is located in the center of a large pineapple planation.

\section{Water quality analysis}

Sampling took place during four distinct time periods in 2015 and 2016: March and early May representing the dry season with September and November representing the wet season. Each site represents various portions of the corridor that are areas of concern (affected by pollution sources such as agricultural inputs, neighborhood septic, and greywater or some industrial sources) or part of a preservation area. We sampled eight times during 2 years, distributed evenly in the wet and dry seasons, except for RG-BS (seven total samplings) as it was not included in the study until May 2015.

We collected aquatic insect samples using EPA rapid bioassessment protocols (Barbour et al. 1999) modified using a square net in place of a kick net. The square net was placed on the streambed directly below a riffle and facing against the current. Substrate was disturbed by kicking the area above the net to collect a representative sample of macroinvertebrates. We repeated this at different riffles to collect enough insects to adequately represent insect composition at each station. Macroinvertebrates were sorted and identified to family using multiple taxonomic guides (Springer 2010; Fernández and Domínguez 2001).

Biological, physical, and chemical parameters were either measured and recorded on-site using a water quality meter 
(Yellow Springs Instrument Company 556 Multiprobe) or taken back to the laboratory for further analysis. Measures of discharge were calculated using a flowmeter and measured stream profiles. At each site, a water sample for bacterial testing was collected using a sterile $100 \mathrm{ml}$ plastic bottle. Water was filtered onto sterile Nalgene filters then analyzed using the m-coliblue 24 methodology. All E. coli colony-forming units were counted. Nutrient samples were collected in acidwashed 125-ml Nalgene bottles and analyzed using persulfate digestion with an auto-analyzer.

The BMWP-CR index was calculated using the Costa Rican Ministry of the Environment and Energy documentation (MINAE 2007). Identified families of insects are assigned a tolerance value with the sum of the values producing an index of water quality using the same BMWP-CR index document. The PMA index was calculated based on methodology of Novak and Bode (1992). For this methodology, insects identified to order are compared to a reference site (for this analysis, we used LR). Water quality scores are based upon the absolute difference between a measured site and the reference composition of insects representing excellent water quality.

PMA is a simplified index where collected aquatic insects are easily identified and processed. For use within communities, a worksheet to calculate water quality was created (Fig. 2). To test the ability of communities to calculate water quality using the PMA index, an identical aquatic insect sample collected during water quality sampling and previously analyzed at LR (the reference condition) was given to volunteers for analysis. The PMA index worksheet (Fig. 2) developed for use in communities accompanied the samples. Volunteers were identified by ASADAS in each community as individuals interested in water quality. Additionally, two students studying water quality in Costa Rica were asked to complete the worksheets. Each volunteer identified the insects based on descriptions and drawings on the worksheet and calculated the PMA index. The PMA index is directly compared to our analysis to determine if volunteers are capable of making adequate water quality predictions.

\section{Statistical analysis}

All statistical tests used XLSTAT software, version 18.1. Means and standard deviations for Table 1 were generated using descriptive statistics. The univariate plots (Figs. 2, 3, 4 , and 5) were tested using model generation ANOVA with Tukey's honestly significantly different (HSD) test applied to test differences between means. Standardized residuals were examined for fit within the $95 \%$ interval of normality. This test determined the difference between each $E$. coli and total phosphorus mean we measured. Any significant difference is noted. Spearman's rank correlation matrix in Table 2 is used to determine correlations (relationships) among the variables.

\section{Results}

Our analysis is based upon four central ideas: land use surrounding rivers, bacterial contamination, nutrient enrichment, and citizen science. Each idea is analyzed separately.

\section{River characteristics and land use}

Each of distinct river basins exhibits unique characteristics (Table 1). Flow changes (particularly in the dry season) result from a variety of land use types including primary cloud forest, montane forest, urban development, concentrated neighborhoods, pasture, hydroelectric plants, pineapple plantation, and various crop productions including sugar cane and palms and concentrated aquaculture of shrimp (personal observations of the watershed). Reduced flows at the lowest elevations are due to diversions.

Rivers in the upper portion of the watershed are headwater and larger with widths less than $10 \mathrm{~m}$. Larger streams occur in the mid elevations with widths between 10 and $20 \mathrm{~m}$. The largest streams studied are over $20 \mathrm{~m}$ in width. Streams in these areas near the coast are channelized and altered through water diversions and riverbed mining. During the dry season, they are greatly reduced in width. The exception to this pattern is along Rio Aranjuez pertaining to the width of the river but not for discharge (Table 1).

Land use throughout this study is highly variable (Table 1). The Monteverde regions (RMV and BS) form the headwater regions of the Guacimal River. This area contains abundant biological forest reserves providing protective services for water quality. The area is rich in faunal biodiversity attracting over 250,000 visitors each year. Ecotourism is a vital enterprise, and protection of this area is critical to maintain this industry. Thus, ecotourism dollars and PSA under forestry law protect water quality here. Resultant water quality is excellent, stream flow is relatively stable, and residents are highly protective of these areas.

Along a similar elevation, the headwaters of the Lagartos River originate in the city of Santa Elena (LL). This city is the business hub of the Monteverde region with hotels, restaurants, and businesses. The business district roads are paved unlike other areas. The town is served by septic and greywater systems. Septic leachate, greywater, stormwater, and untreated sewage enter rivers throughout the area.

Along the mid elevation of the slope (BC, PG, LG, LR, $\mathrm{CM}$ ), a different dynamic occurs. While some ecotourism exists (it is a drive-thru area to Monteverde), it does not predominate the economy of these communities. Hydroelectric generation, farming, and rural agriculture dominate the landscape. The need to generate income through the use of these natural resources precludes a desire to protect them. The rivers in this portion of the watershed are very dynamic with $2 \times-5 \times$ changes in the discharge between dry and wet seasons (Table 1). 


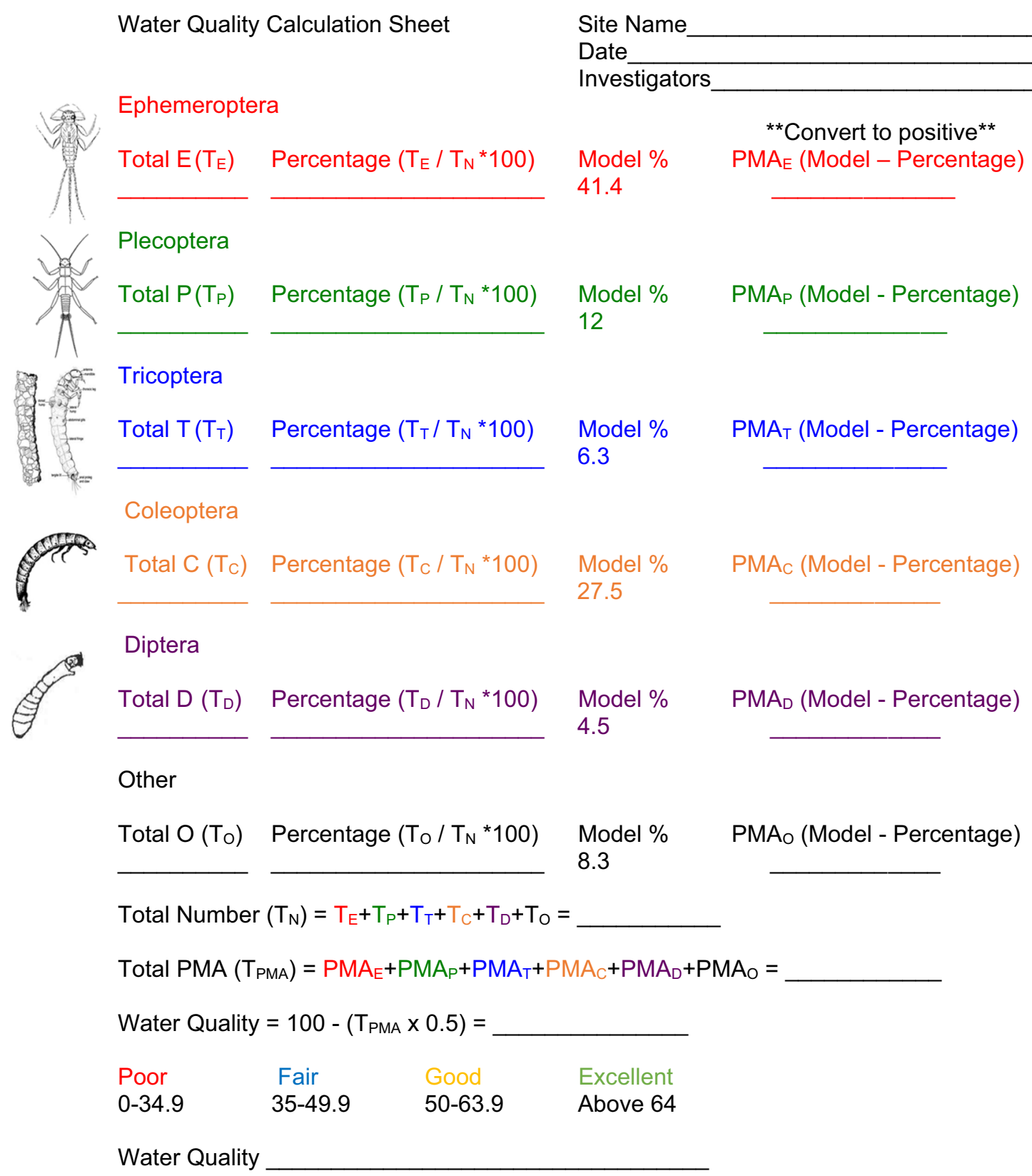

Fig. 2 Water quality calculation worksheet used in the study for the volunteers to test their ability to calculate water quality using the PMA taxonomic calculation. Sheet represents the type of insect identified, the calculation of the index, and the rating of water quality

Residents express concern over pollutants these waters carry and the extent they are impacted particularly during dry season.

The coastal areas not developed for ecotourism are quite dissimilar from other portions of this corridor. Here, SA, LP, LS, and $\mathrm{CH}$ contain extensive high-impact agricultural production. Shrimp farming, pineapple, and sugar cane plantations fill the landscape between river basins. Residents routinely bath, swim, wash clothes, and recreate throughout the rivers (personal observations). Water flows are astonishing low during dry season. Irrigation diverts water to irrigate crops. Riverbed mining is common. Flows change dramatically between wet and dry seasons (up to $12 \times$ ).

\section{Bacteriological results}

Concentrations of $E$. coli bacteria in each river create a discernable pattern. In the upper most headwater regions associated with sampling sites flowing from or in the areas with PSA protection, levels of bacteria are below $125 \mathrm{cfu} / 100 \mathrm{ml}$ (this level of contamination is the suggested guideline for recreational and domestic use; Fig. 3). These results are similar in 
Table 1 General description of each sampling site organized by river basin, elevation, description of land use, width, and average flow per season

\begin{tabular}{|c|c|c|c|c|c|}
\hline \multirow[t]{2}{*}{ Site } & \multirow[t]{2}{*}{ Elevation (m) } & \multirow[t]{2}{*}{ Description } & \multirow[t]{2}{*}{ Width (m) } & \multicolumn{2}{|c|}{ Average flow (1/s) } \\
\hline & & & & Dry season & Wet season \\
\hline \multicolumn{6}{|l|}{ River basin: Guacimal } \\
\hline Biological station (BS) & 1555 & Primary cloud forest & 1.8 & $21 \pm 6$ & $42 \pm 12$ \\
\hline Monteverde Reserve (RMV) & 1450 & Primary cloud forest & 4.6 & $308 \pm 287$ & $326 \pm 185$ \\
\hline Rio Vera Cruz (LR) & 653 & Montane forest & 7.8 & $342 \pm 337$ & $3126 \pm 1849$ \\
\hline Pueblo of Guacimal (PG) & 306 & Pasture & 20.9 & $997 \pm 782$ & $2645 \pm 1705$ \\
\hline Pueblo of San Augustine (SA) & 23 & Crop production & 8.8 & $1038 \pm 1492$ & $2910 \pm 2311$ \\
\hline \multicolumn{6}{|l|}{ River basin: Lagartos } \\
\hline Barrio of Las Llanos (LL) & 1220 & Concentrated neighborhood & 2.6 & $181 \pm 322$ & $216 \pm 160$ \\
\hline Finca of Laguaria (LG) & 336 & Pasture & 13.6 & $577 \pm 513$ & $2510 \pm 1371$ \\
\hline Barrio of La Pita (LP) & 113 & Neighborhood & 24.5 & $1015 \pm 1131$ & $2910 \pm 2311$ \\
\hline Finca of Largarto Sur (LS) & 15 & Crop production & 21.3 & $388 \pm 515$ & $4607 \pm 3497$ \\
\hline \multicolumn{6}{|l|}{ River basin: Aranjuez } \\
\hline Pueblo of Bajo Caliente (BC) & 568 & Montane forest & 15.9 & $1752 \pm 1448$ & $3408 \pm 1742$ \\
\hline Utility location of Casa Maquina (CM) & 280 & Hydroelectric plant & 18.4 & $2990 \pm 3532$ & $3126 \pm 1849$ \\
\hline Pineapple plantation $(\mathrm{CH})$ & 33 & Pineapple plantation & 26.6 & $1661 \pm 2816$ & $7273 \pm 1303$ \\
\hline
\end{tabular}

Average flow is calculated as mean with standard deviations for the dry (March and May) and wet (September and November) seasons. Land use determinations were based upon GIS mapping (Randy Chinchilla, personal communication)

the dry season across the headwaters of each of the river systems. The exception is within the Los Llanos (LL) neighborhood where $E$. coli measures exceeded suggested guidelines regardless of the season.

During the wet season, all of the streams increase in bacterial concentrations (Fig. 3). Even within the upper regions of the corridor (RMV) and (BC), elevated levels of $E$. coli occur. At the biological station (BS), however, E. coli was nearly identical between seasons. As the biological station is remote and without disturbance, this finding suggests limited human activity minimizes bacteria during the rainy season. While it is possible to hypothesize wildlife and alternative sources are responsible for elevated results at other stations, the results at BS suggest otherwise. These results compared to elevated bacteria at Los Llanos (LL) in all seasons suggest human activity is the primary driver of bacterial contamination.

At mid-level sites, we find greater distinction between wet and dry seasons (Fig. 3). Bacterial contamination is below levels of concern $(<125 \mathrm{cfu} / 100 \mathrm{ml})$ during the dry season but largely exceeds these levels across all stations during the wet season. The stations in the Lagartos River (LG) and Guacimal River (PG) are higher relative to the other sites. These sites are surrounded by pasture. LR contains PSA forest buffer, and CM is primarily forest as well.

The lower portion of the watershed suggests a differing view of bacterial water quality (Fig. 3). Within the intensive crop production and neighborhood development, bacterial concentrations in the river remain near levels of concern during the dry season. Stations associated with neighborhood discharge (LP, LS, and SA) are very high during the wet season. At $\mathrm{CH}$, the pineapple monoculture appears to provide a buffering effect from bacterial contamination. More likely, it is the absence of household discharge in the area.

Throughout the watershed, the pattern of bacterial contamination could be attributed to behavioral aspects of the population. Concentrated neighborhood development with greywater and septic water inputs upon a small stream suggests contamination in both wet and dry seasons. Intensive farming practices coupled with towns or neighborhoods present high contamination potential during the wet season.

\section{Nutrient enrichment}

River nutrient enrichment occurs from the loading of nitrogen as nitrate or ammonia, and phosphorus measured as total phosphorus (TP). These nutrients foster the growth of E. coli and, once in the water course, lead to eutrophication of the rivers and mangrove estuaries. Similar to bacterial contamination, sources of nutrients occur in greywater, sewage, agricultural runoff, and intensive crop production.

The nutrient enrichment of the Guacimal River (Fig. 4) demonstrates the protective capacity of surrounding forest in the headwaters. The concentrations of TP in the reserve (MVI) are generally low and consistent throughout all seasons. This is encouraging and suggests adequate PSA forest buffer protects river systems from nutrient enrichment. Water flowing 

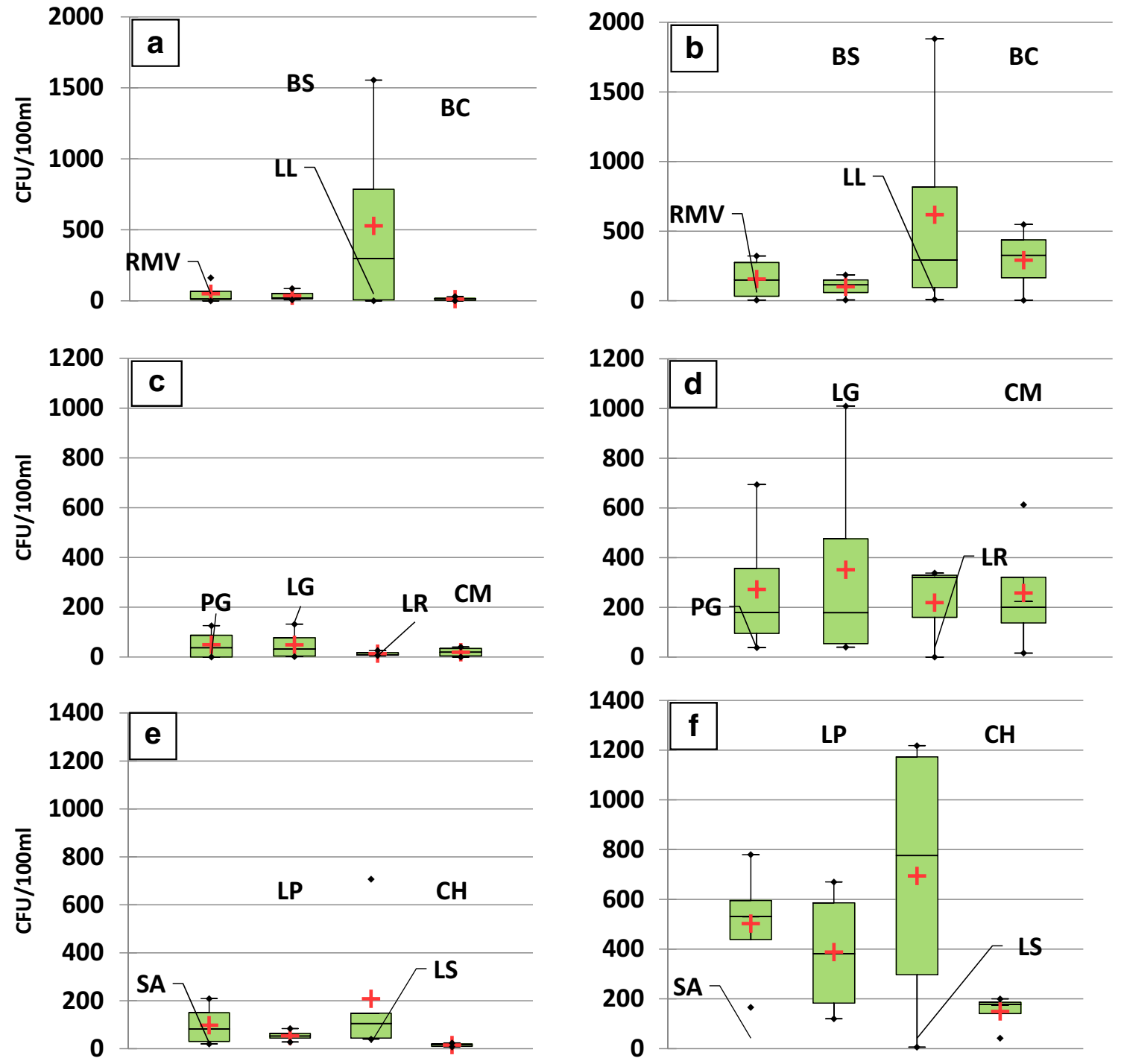

Fig. 3 Abundance of E. coli in streams in the upper $(\mathbf{a}, \mathbf{b})$, mid $(\mathbf{c}, \mathbf{d})$, and lower (e, f) regions of the corridor. Observations during the dry season (March and May; left panels) and wet season (September and November;

from this area into the mid slope through the town of Guacimal is enriched up to fourfold with even higher measures occurring at varying times throughout the year. This enriched water presents a danger to recreational use, changes to the ecological balance, and growth of bacteria, algae, and other undesirable by-products.

Enrichment of waters in the Aranjuez River suggests an alternative scenario (Fig. 4). The headwaters become enriched (at $\mathrm{BC}$ ) but flow through the mid slope, generating minimal additions of TP. The structure of this river is quite different both physically and topographically. While the station at CM includes hydroelectric facilities, these processes do not appear to enrich the water. Surprisingly, the pineapple plantation suggests minimal impact and nutrient loading at $\mathrm{CH}$. This river has the highest flow rates of any river in the study. This increased rate of flow appears to insulate any impacts from

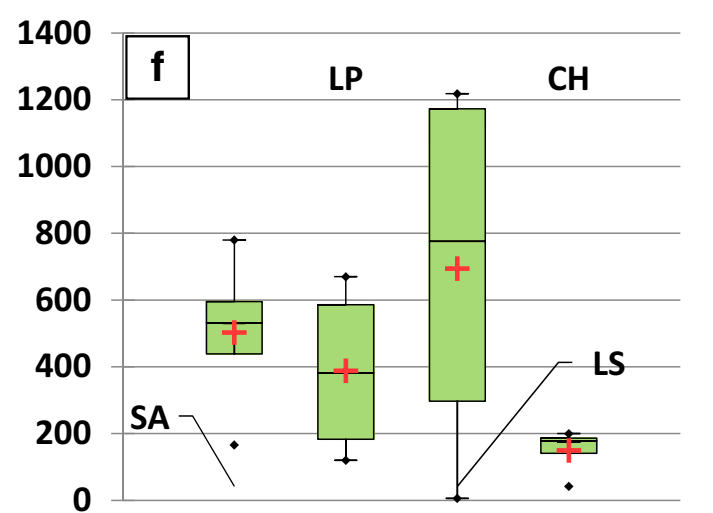

right panels). Abundance in colony-forming units (cfu)/100 $\mathrm{ml}$ and stations are identified in the text

surrounding land disturbance activities. Also, this river is isolated from significant pasture and concentrated neighborhood inputs, suggesting these are the critical inputs for enrichment.

The Lagartos River presents yet another pattern (Fig. 4). The headwaters are highly contaminated compared to protected areas such as BC and RMV. The wastewater of the neighborhood area (LL) is likely responsible as no other contamination sources are present. Enrichment continues down the slope through the pasture areas. No significant reduction of nutrients occurs at any point along this river.

Nutrient enrichment in the corridor appears to be both river and land use dependent. The Aranjuez River is of moderate to good quality, stemming from high flows and minimal household or agricultural development. Minimal development in the upper portions of the watershed appears to buffer nutrient enrichment though intensive agricultural production in the 

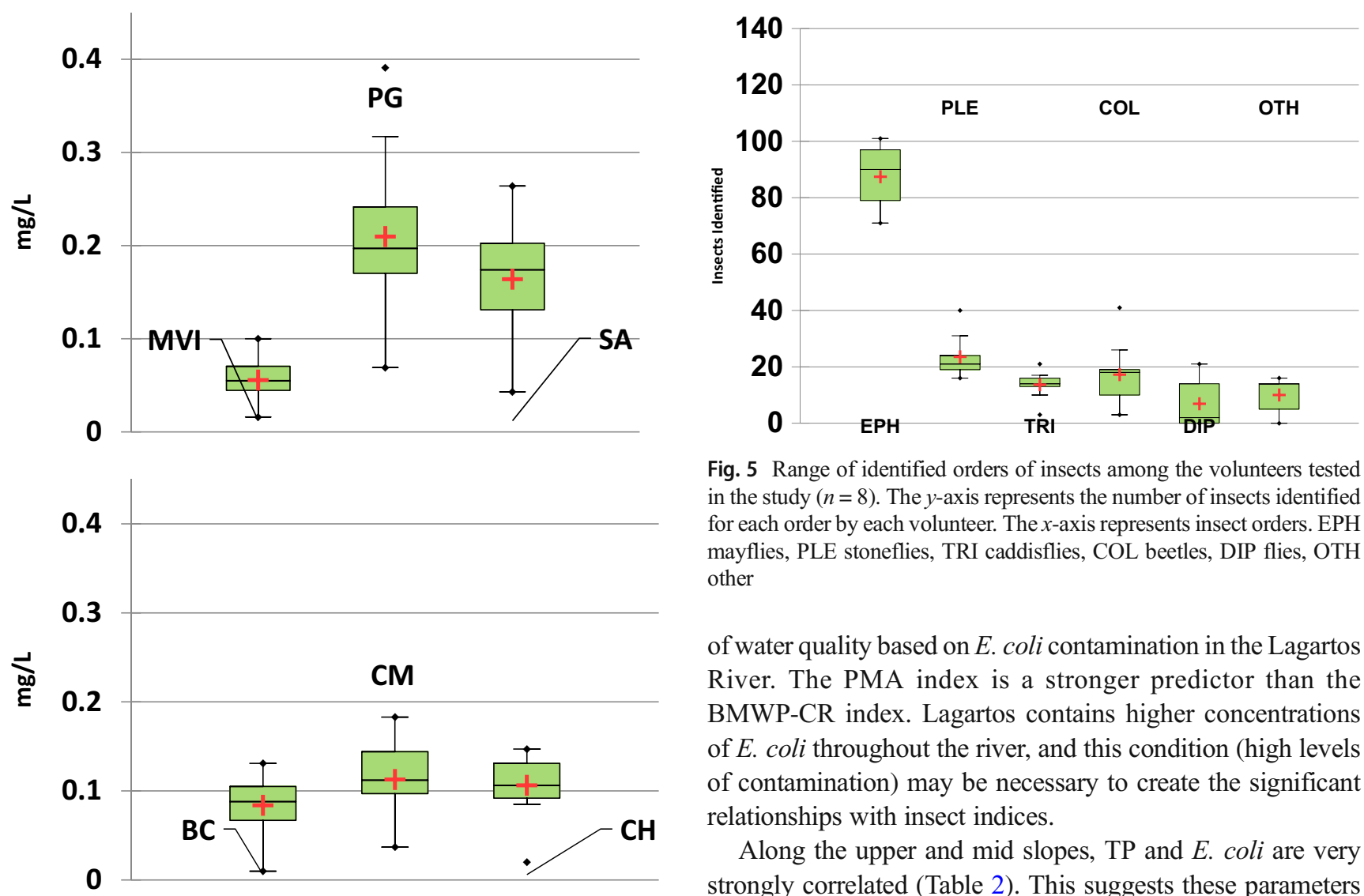

Fig. 5 Range of identified orders of insects among the volunteers tested in the study $(n=8)$. The $y$-axis represents the number of insects identified for each order by each volunteer. The $x$-axis represents insect orders. EPH mayflies, PLE stoneflies, TRI caddisflies, COL beetles, DIP flies, OTH other

of water quality based on $E$. coli contamination in the Lagartos River. The PMA index is a stronger predictor than the BMWP-CR index. Lagartos contains higher concentrations of $E$. coli throughout the river, and this condition (high levels of contamination) may be necessary to create the significant relationships with insect indices.

Along the upper and mid slopes, TP and E. coli are very strongly correlated (Table 2). This suggests these parameters equally reflect contamination. PMA index and $E$. coli are significantly correlated along the mid slope. Results suggest the PMA index is useable as a predictor of water quality in the corridor.

Testing using volunteers produced a PMA index value very similar to calculated values in our study (Fig. 5). Correct identification is important for this calculation. While the greatest variabilities were within Ephemeroptera and Diptera identifications, this did not impact the data enough to produce a spurious calculation. Volunteers confused Ephemeroptera with Plecoptera and often Diptera with Coleoptera.

Statistical comparisons of the testing were excellent (Table 3). PMA index calculation using volunteers was nearly identical to the measured index in the study. This suggests community volunteers are capable of providing water quality index calculations similar to more sophisticated scientific studies. While community volunteers are capable of misidentification (Fig. 5), this error did not cause a change in the predictive ability of the index (Table 3 ). wastewater and agricultural impacts directly pollute the rivers in areas where these land uses predominate.

\section{Citizen science through water testing: using insect indices}

Correlations between studied indices and water quality were varied (Table 2). Both insect indices are significant predictors

\section{Discussion}

Bacteriological results suggest contrasting contamination of rivers occurs between areas representing land use and wet and dry seasons. These findings delineate areas of concern and subsequent analysis. Three identified land use types 
Table 2 Results from statistical correlation analysis among all sites organized for each river basin (Guacimal, Aranjuez, and Lagartos) and by elevation (upper, mid, and lower)

\begin{tabular}{|c|c|c|c|c|}
\hline & E. coli & $\mathrm{TP}$ & BMWP-CR & PMA \\
\hline \multicolumn{5}{|l|}{ Guacimal } \\
\hline E. coli & 1 & -0.079 & 0.174 & 0.127 \\
\hline $\mathrm{TP}$ & -0.079 & 1 & 0.040 & -0.211 \\
\hline BMWP-CR & 0.174 & 0.040 & 1 & 0.028 \\
\hline PMA & 0.127 & -0.211 & 0.028 & 1 \\
\hline \multicolumn{5}{|l|}{ Aranjuez } \\
\hline E. coli & 1 & -0.024 & 0.227 & 0.126 \\
\hline $\mathrm{TP}$ & -0.024 & 1 & 0.325 & 0.111 \\
\hline BMWP-CR & 0.227 & 0.325 & 1 & 0.288 \\
\hline PMA & 0.126 & 0.111 & 0.288 & 1 \\
\hline \multicolumn{5}{|l|}{ Lagartos } \\
\hline E. coli & 1 & 0.304 & $0.351^{*}$ & $0.619^{*}$ \\
\hline $\mathrm{TP}$ & 0.304 & 1 & 0.489 & -0.037 \\
\hline BMWP-CR & $0.351^{*}$ & 0.489 & 1 & -0.087 \\
\hline PMA & $0.619^{*}$ & -0.037 & -0.087 & 1 \\
\hline \multicolumn{5}{|l|}{ Upper } \\
\hline E. coli & 1 & $0.878^{* *}$ & 0.040 & 0.081 \\
\hline $\mathrm{TP}$ & $0.878^{* *}$ & 1 & -0.045 & 0.060 \\
\hline BMWP-CR & 0.040 & -0.045 & 1 & -0.018 \\
\hline PMA & 0.081 & 0.060 & -0.018 & 1 \\
\hline \multicolumn{5}{|l|}{ Mid } \\
\hline E. coli & 1 & $0.412^{*}$ & 0.188 & $-0.256^{*}$ \\
\hline $\mathrm{TP}$ & $0.412^{*}$ & 1 & 0.157 & 0.210 \\
\hline BMWP-CR & 0.188 & 0.157 & 1 & 0.307 \\
\hline PMA & $-0.256^{*}$ & 0.210 & 0.307 & 1 \\
\hline \multicolumn{5}{|l|}{ Lower } \\
\hline E. coli & 1 & 0.017 & -0.107 & 0.324 \\
\hline $\mathrm{TP}$ & 0.017 & 1 & 0.332 & 0.174 \\
\hline BMWP-CR & -0.107 & 0.332 & 1 & $0.411^{*}$ \\
\hline PMA & 0.324 & 0.174 & $0.411^{*}$ & 1 \\
\hline
\end{tabular}

Significant relationships are presented in italics and marked with a single asterisk for significance at $p<0.05$ and double asterisks for significance at $p<0.01$

(urban, agricultural, and preservation) create unique water quality characteristics for rivers flowing through each of them. These characterizations are subject to seasonal variation. First, all land use types show greater contamination in the wet season with the exception of the urban (LL, Fig. 2) site that is contaminated (greater than $125 \mathrm{cfu} / 100 \mathrm{ml}$ ) in both wet and dry seasons. This observation leads to multiple interpretations. Domestic sewage (both septic tank and greywater) pollutes urban streams continuously. This confirms the observations of Bower (2014), suggesting pollution of streams occurs from inadequate sanitation (collection and treatment of wastewater) and uncontrolled urban development. Additionally, sewage contaminated aquifers may occur in these areas as the
Table 3 Comparisons of volunteer identification and PMA index direct water quality calculation at the LR site during the study

\begin{tabular}{lll}
\hline Statistic & Volunteer & LR \\
\hline Number of observations & 10 & 8 \\
Minimum & 72.180 & 56.000 \\
Maximum & 99.545 & 92.080 \\
1st quartile & 74.025 & 73.465 \\
Median & 78.485 & 79.640 \\
3rd quartile & 79.438 & 88.880 \\
Mean & 78.962 & 79.165 \\
Variance $(n-1)$ & 62.155 & 142.812 \\
Standard deviation $(n-1)$ & 7.884 & 11.950 \\
\hline
\end{tabular}

connection between contaminated rivers and groundwater is unknown. Twenty-seven percent of the Costa Rican population drinks water contaminated with fecal coliform and parasites according to the National Water Laboratory (Mata 2010). Rivers in this sense may act as polluting sources to drinking water.

Linking water-borne illness to this potential contamination is of concern. Resources spent for treating diarrheal diseases are often four times the potential cost of monitoring water and sanitation systems (Ballestero et al. 2007). Inadequate sanitation, as suggested by our high bacterial contamination observations, burdens health care systems. Solutions to this problem are elusive. Building and maintaining wastewater treatment plants is not a solution. Current wastewater treatment plants are not well maintained in Costa Rica, have unrepaired structural damage, discharge untreated wastewater directly to surface water, or are blocked by buildup of sewage sludge (Bower 2014). Rates of septic system failures are poorly understood and may exceed 70\% (Withers et al. 2014). Wastewater treatment is one of the greatest environmental challenges currently in Costa Rica.

Yet, management is not given needed funding or regulation. Water supply is given top priority with $82 \%$ of waterrelated government funding directed toward drinking water projects. Further, no identifying agency, program, or law is directly assigned to protect rivers from inadequate sanitation. Schwarzenbach et al. (2010) provide strong epidemiological evidence, suggesting reductions in the burden of disease occur with improved sanitation. But, water laws are written to promote protection but are poorly enforced. The 1942 Water Law in its current form promotes economics while allowing agriculture and direct wastewater and stormwater inputs into rivers. And, concerns grow over contamination of aquifers. Awomeso et al. (2010) demonstrated the persistence of groundwater contamination seeping from sewage lagoons associated with agriculture and CAFOs. Bower (2014) suggests nitrates are building in the groundwater supply. This problem cannot be continually ignored. 
Agricultural impacts linked to tropical river dynamics

Additionally, river dynamics unique to tropical systems may influence water quality. Based on our data, higher river discharge through the dry season coupled with headwater riparian buffer and limited domestic development seems to buffer a river from water quality degradation. Hence, high river discharge potentially provides a dilution effect mitigating agricultural land uses and pollution. Connolly et al. (2015) suggest river flow dilution effect may be a significant controller of water quality in headwater streams. This agrees with our observations in this corridor. Unfortunately, dry season eliminates this dilution dynamic. Low discharge coupled with headwater urban and mid-slope agricultural pollution impaired water quality based on our observations. And, many residents rely heavily on river use during these dry periods. So during dry periods, when river water is needed the most, residents potentially increase their exposure to disease.

Overall land use development should be given much more importance in managing river systems (Banks et al. 2011). Also, geology and sediment load with size and shape of a watershed needs consideration as well (Wohl et al. 2012). The Lagartos River originating in an urban area and with the lowest observed flow was the most degraded river. The Guacimal River while heavily impacted along the headwater region receives protected PSA forest river flow from the Vera Cruz at mid slope, mitigating water quality declines from otherwise urban and agricultural pollutants. The Aranjuez River originating from PSA forests and with steep channels and limited development had the best overall water quality. Each river system is dependent upon unique characteristics contained within the watershed and should be managed accordingly.

While our results suggest pineapple agriculture appears protective from bacterial contamination, it does not describe the overall water quality impact from this type of land use. Pineapple monoculture often modifies stream channels, pollutes water with agrochemicals, adds sediment and waste to surface water, and destroys wetlands (Bower 2014). We conclude that because this plantation is so close to the entrance into the Gulf of Nicoya, water quality degradation occurs beyond our sampling point. Also, a considerable amount of diversion occurs though the plantation without return. The diverted water potentially carrying a considerable pollutant load enters the aquifer. Drinking water contamination is a real possibility in this area.

\section{Mechanisms of water quality protection}

Natural systems appear to provide the most significant water protection programs in Costa Rica. Our experience suggests payments for environmental services (PSA) are the primary protector of water quality. This is why we suggest community science and monitoring as a critical need to improve sanitation. PSA programs are centered on maintaining adequate supply for hydroelectric programs or protection of aqueducts that forest infiltration supplies. These decisions are local and driven toward the creation of PSA forest when they make economic and environmental connections to owners. But indirectly, this program provides improved water management for entire communities. While water quality or river flow is not included in these payments, downstream areas benefit. As we observed in the Lagartos River, poor water quality in the absence of PSA forest in the headwaters flows all of the way into the gulf.

No other known program or legislation produced a similar result based on our observations. In fact, the lack of legislation allows direct withdraw in the heavily agricultural portions of the corridor. And, the resultant water quality is poor. Further, a citizen science initiative would create even greater support for the corridor concept, moving the PSA forest thinking throughout the studied region. A study by Wood et al. (2017) supports that within biological corridors, protection of forest creates positive environmental perceptions, thus encouraging conservation. Our study supports the idea that surrounding PSA units, individuals, and businesses expect good water quality, but outside of these units, water quality is poorly understood. Thus, without significant point and non-point pollution legislation, the corridor concept is critical to the overall water health of these communities.

\section{Concerns from climate change will be difficult to absorb}

Models suggest increasing temperatures (up to $3.8 \mathrm{C}$ by the year 2100) and reduced precipitation during the dry season of up to 14\% (Karmalkar et al. 2011; Ray et al. 2006) will change current corridor hydrology. Because river discharge is linked to levels of contamination, a river system now considered not impaired may begin to degrade without changes in land use. Continued deforestation of lowland forests (outside areas of PSA but still within the corridor) will worsen these conditions. Cloud forest preservation and capture of more area into the PSA program may be critical, moving forward to protect water quality. As Postel and Thompson (2005) suggest environmental services from cloud forest become ever more important as climate change reduces river discharge. Therefore, development and acceptance of the corridor concept is at a critical time. Communities need to embrace water protection now so they may maintain flexibility to adapt.

Current sanitation practices, uncertain groundwater connections with river contamination, and reliance on the spot PSA program for protection are not effective future strategies. Nor is a single-minded water management focused solely on drinking water with wastewater given low priority. Communities need engagement into water issues to drive local 
and collective governmental agencies to react. It is our contention that driven community science and water quality monitoring is the first step toward a much greater water management vision.

\section{Community engagement in water quality problems as a solution}

All studied river systems are integral parts of communities in the biological corridor. River physical characteristics (flow, color, and smell) generate impressions of community health. Within areas surrounded by tropical montane cloud forest and part of a PSA program, good water quality is real and beneficial for the community and ecotourism. It is part of the fabric of that community, helps drive economic prosperity, and is a natural by-product of a positive environmental ethic. Community engagement is natural because success of water resource management program benefits the PSA.

Outside PSA areas, residents have a very different perception. Awareness of water quality concerns is real but delegated to government programs. Residents perceive AyA and ASADAS as the entities necessary to provide clean and healthy water exclusively. With the belief these entities are successful in providing quality drinking water, pollution sources are generally ignored. But, quality drinking water throughout this area may be an illusion. In areas of high precipitation, the infiltration of polluting agents potentially toxic to human health may be from 30 to $50 \%$ (Ballestero et al. 2007). And if these pollution agents are measured in river, water quality concerns should be heightened over what residents are actually ingesting. Disease may occur without clear connections to sanitation or other causes.

The direct measure of aquatic insects in rivers with water quality interpretation is a vehicle to this awareness and change. Using the simplified index (PMA), an ASADAS or community group can provide information otherwise unavailable to residents. The established index (BMWP-CR) is too complex and limited to water quality professionals. Armed with community water health information this index provides, areas of contamination and needed water improvement areas can be identified. Water quality can be continually monitored and used along various reaches of the river to pinpoint potential elicit discharges or community wide problems. It will provide ASADAS in communities with a tool toward improvements in sanitation. And, this information can begin an improved legal framework for river protection.

Engagement of residents into citizen science is critical. Our results suggest citizens are quite capable in analyzing water quality using insect populations and in agreement with Dickinson et al. (2010). While these indices are not necessarily explicit in making clear water quality determinations, they do provide a sorely needed tool in an overall water management program. Residents involved can establish long-term monitoring stations and organize efforts to improve water quality. Work to coalesce residents throughout a corridor can rally around use, comparison, and information workshops using water quality as a theme. Citizen science can bring real change to these communities.

\section{Conclusion}

While potable drinking water is in adequate supply for citizens in Costa Rica, sanitation management is nearly non-existent. Links between drinking water and sanitation are unknown, but rivers carry a high burden of pollutants from various land uses and human waste contamination. We argue that a comprehensive watershed management using water quality identification and embedded into the strength of the forestry law, PSA program, and corridor management will improve these problems. This can lead to an established program where communities install best management practices for agricultural, greywater, and stormwater runoff. Compensated by agribusiness or multinational CAFOs or fees for use, corridors can establish water protection programs similar to existing programs in the USA (USEPA 2008). If driven by community activism, corridors can create water quality improvement districts. This practice can empower corridors toward meaningful water quality protection.

A system where PSA environmental services payments are expected to bare the sole burden for water quality improvement is not sustainable. We believe water quality monitoring in communities will bring about needed engagement and support for management programs. Communities using monitoring information can organize efforts, demonstrating their commitment to improve water quality and bringing needed political change in existing legislation. We believe that only when communities are engaged and significantly improving the water around them that the legal framework will support the protection of water resources through wastewater treatment and sanitation.

Open Access This article is distributed under the terms of the Creative Commons Attribution 4.0 International License (http:// creativecommons.org/licenses/by/4.0/), which permits unrestricted use, distribution, and reproduction in any medium, provided you give appropriate credit to the original author(s) and the source, provide a link to the Creative Commons license, and indicate if changes were made.

\section{References}

Amador J, Alfaro E, Lizano O, Magaña V (2006) Atmospheric forcing in the Eastern Tropical Pacific: a review. Prog Oceanogr 69:101-142

Andersson K, Gibson C (2006) Decentralized governance and environmental change. J Policy Anal Manag 26:99-123 
Arias A (2010) Situación de Potabilización y Saneamiento en Costa Rica. En: Decimosexto In- forme Estado de la Nación en Desarrollo Humano Sostenible. 36 pp.

Awomeso A, Taiwo A, Orebiti O, Orekoya A, Odjegba E (2010) Effect of untreated sewage dump on the quality of groundwater in Iddo Community, Lagos Nigeria. J Agric Sci Env 10:98-106

Ballestero M, Reyes V and Astorga Y (2007) Groundwater in Central America: its importance, development and use, with particular reference to its role in irrigated agriculture. No. H040044, IWMI Books, Reports, International Water Management Institute.

Barbour M, Gerritsen J, Snyder B, and Stribling J (1999) Rapid bioassessment protocols for use in streams and wadeable rivers: periphyton, benthic macroinvertebrates and fish, Second edition. EPA 841B-99-002. U.S. Environmental Protection Agency; Office of Water; Washington, D.C.

Banks E, Simmons C, Love A, Shand P (2011) Assessing spatial and temporal connectivity between surface water and groundwater in a regional catchment: implications for regional scale water quantity and quality. J Hydrol 404:30-49

Bradley R \& Diaz H (2010) Regional-scale climate change: observations and model simulations. U.S. Department of Energy, Climate Change Prediction Program Office of Energy Research.

Bower K (2014) Water supply and sanitation of Costa Rica. Environ Earth Sci 71:107-123

Burkholder J, Libra B, Weyer P, Heathcote S, Kolpin D, Thorne P, Wichman M (2007) Impacts of waste from concentrated animal feeding operations on water quality. Environ Health Perspect 115: 308-312

Cairns J, Pratt J (1993) A history of biological monitoring using benthic macroinvertebrates. In: Rosenberg DM, Resh VH (eds) Freshwater biomonitoring and benthic macroinvertebrates. Chapman \& Hall, New York

Connolly N, Pearson R, Loong D, Maughan M, Brodie J (2015) Water quality variation along streams with similar agricultural development but contrasting riparian vegetation. Agric Ecosyst Environ 213:11-20

Conrad C, Hilchey K (2011) A review of citizen science and communitybased environmental monitoring: issues and opportunities. Environ Monit Assess 176:273-291

Dallas S, Scheffe B, Ho G (2004) Reedbeds for greywater treatmentcase study in Santa Elena-Monteverde, Costa Rica, Central America. Ecol Eng 23:55-61

de la Cruz E, Bravo-Durán V, Ramírez F, Castillo L (2014) Environmental hazards associated with pesticide import into Costa Rica, 1977-2009. J Environ Biol 35:43-55

de Albuquerque C (2009) Promotion and protection of all human rights, civil, political, economic, social and cultural rights, including the right to development; report of the independent expert on the issue of human rights obligations related to access to drinking water and sanitation. In: Addendum: mission to Costa Rica; report to the United Nations General Assembly.

Delgado-Serrano M, Mistry J, Matzdorf B, Leclerc G (2017) Community-based management of environmental challenges in Latin America and the Caribbean. Ecol Soc 22:4

Dickinson J, Zuckerberg B, Bonter D (2010) Citizen science as an ecological research tool: challenges and benefits. Annu Rev Ecol Evol Syst 41:149-172

Echeverría-Sáenz S, Mena F, Pinnock M (2012) Environmental hazards of pesticides from pineapple crop production in the Río Jiménez watershed (Caribbean Coast, Costa Rica). Science Total Environ 440:106-114

Fernández H and Domínguez E (2001) Guía Para La Determinación De Los Artrópodos Bentónicos Sudamericanos, Universidad Nacional De Tucumán, Facultad De Ciencias Naturales e Instituto.
Food and Agriculture Organization (FAO) (2012) The outlook for agriculture and rural development in the Americas: a perspective on Latin America and the Caribbean. FAO, Santiago

Hamilton S (2010) Biogeochemical implications of climate change for tropical rivers and floodplains. Hydrobiologia 657:19-35

Hidalgo HJA, Alfaro E, Quesada B (2013) Hydrological climate change projections for Central America. J Hydrol 495:94-112

Hidalgo León H, Madriz C, Martinez E, Muñoz A, Sandi N, Alvarado D and Salazar V (2015) Urban waters in Costa Rica. In Urban water: challenges in the Americas: a perspective from the academy of science. IANAS. 619 pages

Jacobsen D, Cressa C, Mathooko J, Dudgeon D (2008) Macroinvertebrates: composition, life histories and production. In: Dudgeon D (ed) Tropical stream ecology. Elsevier, New York

Karmalkar A, Bradley R, Diaz H (2008) Climate change scenario for Costa Rican montane forests. Geophys Res Lett 35. https://doi.org/ 10.1029/2008GL033940

Karmalkar A, Bradley R, Diaz H (2011) Climate change in Central America and Mexico: regional climate model validation and climate change projections. Clim Dyn 37:605-629

Karr JR, Chu EW (1999) Restoring life in running waters. Island, Washington, D.C.

Kohlmann B, Arroyo A, Springer M and Vásquez D (2015) Agrorural effects on the macroinvertebrate assemblage in a tropical river. https://doi.org/10.5772/59073

Kumar A, Colton M, Springer M, Trama F (2013) Macroinvertebrate communities as bioindicators of water quality. Environ Sci Pollut Res 23:5983-5991

Kuzdak C, Wiek A (2014) Governance scenarios for addressing water conflicts and climate change impacts. Environ Sci Policy 42:181-196

Macías J, Vargas E, Sracek O (2017) A comparative analysis of two methodologies to estimate well protection zones for transport of viruses from septic tanks in volcanic aquifers in Costa Rica. Environ Earth Sci 76:244

Mata A (2010) 30 percent de usuarios de acueductos rurales recibe agua contaminada. La Nación. San José

Mejia A (2014) Water scarcity in Latin America and the Caribbeanmyths and reality. In: Garrido A, Shechter M (eds) Water for Americas: challenges and opportunities. Routledge, Oxford

Mekonnen M, Pahlow M, Aldaya M, Zarate E, Hoekstra A (2015) Sustainability, efficiency and equitability of water consumption and pollution in Latin America and the Caribbean. Sustainability 7:2086-2112

Miller V, Crespy C, Loess K, Renau J (2010) Western hemispheric trade agreements and sustainability: lesson from butterflies, hummingbirds, and salty anchovies. Sust Dev 18:220-228

Montgomery M, Elimelech M (2007) Water and sanitation in developing countries: including health in the equation. Environ Sci Technol 2007:17-24

MINAE (2007) Regulation for the evaluation and classification of the quality of surface water bodies Executive Decree No. 33903MINAE. Costa Rica

Novak M, Bode R (1992) Percent model affinity: a new measure of macroinvertebrate community composition. J N Am Benthol Soc $11: 80-85$

Pagiola S (2008) Payments for environmental services in Costa Rica. Environ Econ 65:712-724

Plink-Björklund P (2015) Morphodynamics of rivers strongly affected by monsoon precipitation: review of depositional style and forcing factors. Sediment Geol 323:110-147

Postel S, Thompson B (2005) Watershed protection: capturing the benefits of nature's water supply services. Nat Res Forum 29:98-108

Ray D, Nair U, Lawton R, Welch R, and Pielke R Sr (2006) Impact of land use on Costa Rican tropical montane cloud forests: sensitivity of orographic cloud formation to deforestation in the plains. J Geophys Res. doi: 10.102h. 111: 1029- 
Resh C (1995) Freshwater benthic macroinvertebrate and rapid bioassessment procedures for water quality monitoring in developing and newly industrialized countries. In: Davis W, Simon T (eds) Biological assessment and criteria - tools for water resource planning and decision making. Lewis, Boca Raton

Schwarzenbach R, Egli T, Hofstetter T, von Gunten U, Wehrli B (2010) Global water pollution and human health. Annu Rev Environ Resour 35:109-136

Sedeno-Diaz J, Kohlmnan B, Lopez-Lopez E (2012) Benthic macroinvertebrates as indicators of water quality in streams of Costa Rica: using an adaptation of the BMWP score. Transylv Rev Syst Ecol Res 14 "The Wetlands Diversity:177-188

Springer, M. 2010. Biomonitoreo. En: Springer, M., Ramírez A. \& P. Hanson (eds.). Macroinvertebrados de agua dulce de Costa Rica I. Rev Biol Trop 58 (Suppl. 4): 53-59

Sekercioglu C (2009) Tropical ecology: riparian corridors connect fragmented forest bird populations. Curr Biol 19:210-213

Trenberth K, Dai A, Rasmussen R, Parsons D (2003) The changing character of 1011 precipitation. Bull Amer Meteor Soc 84:1205-1217

U.S. Environmental Protection Agency. 2008. EPA water quality trading evaluation final report

Wantzen K, Yule C, Tockner K, Junk W (2008) Riparian wetlands of tropical streams. In: Dudgeon D (ed) Tropical stream ecology. Elsevier, New York
Waylen P, Quesada M, Caviedes C (1996) Temporal and spatial variability of annual precipitation in Costa Rica and the Southern Oscillation. Int J Climatol 16:173-193

Withers P, Jordan P, May L, Jarvie H, Deal N (2014) Do septic tank systems pose a hidden threat to water quality? Front Ecol Environ 12:123-130

Wohl E, Barros A, Brunsell N, Chappell N, Coe M, Giambelluca T, Goldsmith S, Harmon R, Hendrickx J, Juvik J, McDonnell J, Ogden F (2012) The hydrology of the humid tropics. Nature Climate Change 2:655-662

Wood M, Sheridan R, Feagin R, Castro J, Lacher T (2017) Comparison of land use change in payments for environmental services and National Biological Corridor Programs. Land Use Policy 63:440-449

Zamora-Munoz C, Sainz-Cantero C, Sanchez-Ortega A, Alba-Tercedor J (1995) Are biological indices BMWP and ASPT and their significance regarding water quality seasonally dependent? Factors explaining their variations. Wat Res 29:285-290

Zurbrügg R, Wamulume J, Kamanga R, Wehrli B, Senn D (2012) Riverfloodplain exchange and its effects on the fluvial oxygen regime in a large tropical river system (Kafue Flats, Zambia). J Geophys Res 117:G03008. https://doi.org/10.1029/2011JG001853 